\title{
Cultural Resistance in the Discourse and Mbrokohi, Symbolic Ritual of Sedulur Sikep's Rice Harvest in Dukuh Bombong, Baturejo of Pati District
}

\author{
Jarot Kristianto $^{1}$, Bani Sudardi ${ }^{2}$, Warto $^{3}$, Slamet Subyantoro ${ }^{4}$ \\ \{gkjarot_salut@yahoo.com ${ }^{1}$, banisudardi@yahoo.co.id ${ }^{2}$,warto_file@yahoo.com ${ }^{3}$, \\ s.biyantoro@yahoo.co.id $\left.{ }^{4}\right\}$ \\ Universitas Sebelas Maret, Indonesia ${ }^{1,2,3,4}$
}

\begin{abstract}
This study explores on the cultural resistance of a discourse on mbrokohi ritual, it is Sedulur Sikep's rice harvest traditional ceremony held in Sukolilo. This study focuses on exploring the cultural resistance found in the discourse which covers the symbolic meanings reflected in the mbrokohi ritual. This aimed at describing the forms of cultural resistance and steps of anticipation used by the Sedulur Sikep society in implementing the rice harvest ritual mbrokohi towards the stigma and influence of the modern era. The data collection technically applied in-depth interviewing method, involved observations and the analysis of primary/secondary data documents. The stages of analysis were conducted based on a cycle basis which includes data collection, data reduction, data display and verification. The study concludes that traditionally, the mbrokohi rice harvest ritual reflects symbolic eco-ritual, these typical society have been bestowed on the eco-doctrinal of a natural teaching as their discourse of force and symbols which enable the people to fight against any stigma and modern influence of the times where its main concern is to preserve the nature and environmental condition (ecopraxial).
\end{abstract}

Keywords: Discourse, Symbolic Meaning, Ritual, Mbrokohi, Teaching, Sedulur Sikep

\section{Introduction}

Since the invention of the printing press in 1440 which marks the beginning of modern era. The progress of an increasingly modern era marked by a number of discovery tools and sophisticated facilities sustaining human lives such as steam engines, electricity, computers, to internet technology. Along with the advancement of time, human civilization is also increasingly developed and developing. The problem lays on current generations who are deluded on exploiting media, in fact, most people still find it difficult to avoid the effects of technological sophistication, and are absorbed in following the developments. Thus, there are social gaps from each point of view on how to respond to the progress and development of the age. Thus, there are social gaps from each point of view on how to respond to the progress and development of the age.

This might also be applicable to the level of developing traditional and cultural issues. Some people emphasize the need for cultural preservation, there are typical people in nature who withstand to faithfully protect their ancestral heritage. There are those who in fact appreciate and enjoy the modern era and continually seek for new things to satisfy their needs. 
This triggers a large gap between the ancient and modern generations. One of the stigmatic perceptions arises among the society is that they incline to trigger negative impact instead of the positive. Bearing in mind one generation and the other vary in terms of thoughts and perceptions, they defend their own which further followed by resistance both from the discursive theory and actions. The negative impact happens when one parties demeaning other attitudes, this certainly led to the national disintegration and social intolerance.

From such arising complex problems amidst society, social inequality is not limited to classifying between generations. However, it may also occur due to classifying between groups, communities, races and particular people. In this study, the Samin community, hereinafter referred to as Sedulur Sikep, is a group of communities as the object who were being stigmatized. However, they remain sharing similar motivations in maintaining their own traditions and culture, they are able to resist and anticipate for current influence of this increasingly modern era. To examine this problem, Ronald Barthes's semiotic analysis, Michel Foucault's theory of discourse and James Scott's theory of resistance are used.

\section{Methodology}

According to Kirk and Miler [1] qualitative research is a particular tradition in social science fundamentally dependent on observing humans in their own regional areas and dealing with these people in their language and terminology. With regard to such view, this study was designed with qualitative research which culturally examines mbrokohi ritual at Sedulur Sikep community's rice harvest ceremony, which reflects both discourse and symbols forces to fight against both the modern era's stigma and influence, which basically aimed at preserving nature and environment. This study was conducted in October 2018 to June 2019 in Sukolilo of Pati Regency. In this study, the researchers used the interpretivequalitative research model; we wish to create a comprehensive observation on the cultural resistance of the discourse through mbrokohi ritual, a traditional ceremony of Sedulur Sikep rice harvest in Sukolilo. Based on the formulated problem, this study is more focused on the cultural resistance framed by a discourse of symbolic meaning reflected in the mbrokohi ritual procession, a cultural practice of Sedulur Sikep's rice harvest ceremony in Sukolilo. On such background, the data collection was conducted in Bombong, Batureja Village, Sukolilo District, Pati, Central Java Province.

In this study the researchers attempted to explore the symbolic meanings implied in the mbrokohi ritual of the Sedulur Sikep's rice harvest community which reflected the power of discourse and symbols to counter the stigma and influence of the modern era oriented towards preserving nature and the environment. The data collection techniques and the type of study is field work research. The researchers attempted to obtain data and information through making direct observations on the object under study by means of observation, interviews, questionnaires, and documentation. The data collection activities are carried out through systematic observation and recording of the symptoms studied. An interview is an oral question and answer between two or more people. After having gathered primary and secondary data, the researchers then classified and analyzed the data. Data analysis in this study consisted of three activities that occurred simultaneously, namely data reduction, data display/data display, and verification. The three components are carried out interactively between each component as well as the process of collecting data in cycles that are interrelated and take place continuously until complete and data is saturated [2]. In the 
implementation there are three stages of the procedure consisting of the pre-field stage, the stage of field observation, the stage of data analysis, and the stage of preparing the report.

\section{Finding and Discussion}

\subsection{The Uborampe of Mbrokohi Ritual Ceremony in Symbol and the Meanings}

The term mbrokohi in Sedulur Sikep community is synonymously defined as 'selametan' or thanksgiving by inviting friends or neighbors. In this ritual it requires a complete ritual called ubo-rampe. According to the Javanese dictionary of Baoesastra by W.J.S Poerwadarminto, ubo-rampe is panganan lan lelawuhan lsp. kang diaturake marang deduwuran ing nalika duwe gawe, apa-apa sing kalebu prabot utawa kaperluan. The point is food or side dishes that are served at a meeting when someone has an interest party or celebration, the other purpose is a set of tools or equipment needed. In ritual mbrokohi rice harvest aimed at honoring the Goddess Sri for the people of Sedulur Sikep requires an equipment also specifically in the form of food and drinks. Through in-depth interviews with Mr. Kukoh and Mrs. Gunarti a woman leader from Sedulur Sikep explained about ubo-rampe as ritual symbols and their meanings, including: wedang kendi, that is, clear and mature water that is placed in the pottery, a jug made of clay. This is a meaningful sign that the person and soul of the Sedulur Sikep community has a peaceful heart and a clean and soothing mind.

Then sega gudhangan (urap rice) is white rice equipped with boiled kenikir leaf vegetable and given a spicy young coconut shavings and sprouts, sometimes given salted fish. This is a reflection of the symbol that the Sedulur Sikep community as the typical people of sing prasaja ora neka-neka (simple and uncomplicated). The gudhangan rice has been a daily food where rice and vegetables are combined, which is easy to make, the price is cheap and affordable for people in public who intend to serve it.

Furthermore, jenang abang (red porridge) made of the cooked rice then mixed with coconut milk and then stirred with shaved coconut sugar. This Jenang abang made partly together with jenang putih (white porridge) which is made of the cooked rice and is mixed with coconut milk, this part no longer mixed with palm sugar, its serving is mixed into but it is no require to be stirred. The term becomes jenang abang putih, this has the most important symbolic meaning in living the origin of human life. These cultural attributes reflect the central meaning in the cosmological meaning of the origin of human life, especially for the Sedulur Sikep community. The meaning is a dwelling realm between female and male figures who have sex. More simply, the phenomenon that brings together an egg cell with sperm.

In general, people have recognized that women in their cycles experience menstruation marked by bleeding red, this blood color is then symbolized as the red porridge (jenang abang). then in the male figure during intercourse he emits a white liquid called spermatozoa. From this white liquid, it is symbolized by white porridge. The meeting between eggs that have been fertilized by spermatozoa will produce fertilization that develops into a zygote where this has the potential to become a living organism as a human embryo until a human baby manifests in the womb and is ready to be born on earth.

According to the Sedulur Sikep community's belief, humans are born into this world not alone. Man was created there and was born on this earth together with his brother called sedulur papat lima pancer and keblat papat lima pancer. What is meant by sedulur papat is kakangkawah, adi ari-ari, rah, and puser (amniotic fluid, placenta, blood and navel). The 
meaning of lima pancer is the baby or we as individuals. The term keblat papat explains that there are four wind directions where all of them are always together and accompanying humans. Then lima pancer what is meant is the baby or human self as the center (pancer). From this sense they define a philosophical expression sangkan paraning dumadi namely how humans deal with and respond to this life. Sangkan means the origin, paran is a purpose, dumadi is the creator who created.

The last is iwak ingkung as a meaningful symbol sujud manembah (pray and worship) ingkung (the whole cooked chicken) is a native chicken that is tied to its feet and then cooked with an opor seasoning complete with coconut and Salam leaves. The nuances of native chicken usually have better meat tastes and are more expensive than other types of chicken. The term ingkung is derived from an expression iwak kang manekung then its legs were tied. According to Serat Wirid Hidayat Jati the word manekung is a special term that is synonymous with meditation or worship in prayer [3]. Apart from this understanding, ingkung becomes a symbol of animal sacrifice that reflects the meaning of pisungsunging ngaurip (life offerings) are best presented to the Almighty God.

\subsection{Symbols and Meanings as the Force of Discourse}

Michel Foucault calls language "systems of thought" or "systems of ideas" that relate to one another and provide us with knowledge about the world. Foucault discusses language as a system of thought or system of ideas at the level of discourse. For Foucault discourse is the only way for us to understand reality (the world), through discourse it enables individuals to know and explain reality. Discourse is a way of thinking, how to know, and state something. In the interview conducted on Mrs. Gunarti about the reality of life, she stated that "sing ketok wae sing digunem sing ora ketok rasah dirembug" (only the visible are discussed, the invisible does not need to be discussed). This reality shows the discourse on how the Sedulur Sikep members of community pay more attention to what seems to be an important thing to talk about and explain. Thus, it is natural that the Sedulur sikep community never discusses the Allah who is spirit and who does not appear to be invisible.

According to the Blora Resident Assistant report which recorded the interrogation to Sedulur Sikep Surosentiko (the pioneer of the Sedulur Sikep community movement) in 1907 published in Het Nieuws van Den Dag on March 5, 1907. Sedulur Sikep Surosentiko disseminates the subject of his teaching through the answer to the third question, do you believe in Allah or another God? Sedulur Sikep's answer: "No, I have never seen God or another God, so I do not believe". Then the fourth question Do you believe in heaven or hell and life after death? Sedulur Sikep's answer: "No, because I have never seen heaven or hell and also never proven there is life after death". Sedulur Sikep community is accustomed to answering with jarwa dhosok (forced meaning) or kerata basa (backronym) is a phrase formed to mean a word by assuming it is an acronym. When I asked Mbah Sampir, one of the elders in Sukolilo, did you know the spirit? The answer is, "Roh niku goroh wong ra ana kok diomongke ana?" (The spirit is lying; doesn't it seem to be said to exist?) Then I asked him again, do you have and know Gusti Allah? The answer, "Gusti Allah niku bagusing ati karsa ngalah" (God is if someone is kind and willing to budge).

The nature of Sedulur Sikep implied through their discourse is mono-cosmoism which explainable through the fragment of words, mono $=$ the only existence (reality), cosmo or cosmos $=$ the universe, and ism $=$ understanding or belief. Thus. mono-cosmoism means the understanding that believes the only reality is the nature. What exists and what appears is what is seen and proven in the universe and its environment. This understanding has a unique 
significance in relation to the preservation of nature, namely the result of mutual interaction between humans and nature in the interaction of both, which gives a positive behavioral impact. Humans show attitudes that tend to be very respectful of nature and the environment. Thus, the mono-cosmistic community gave rise to certain cultures and traditions to carry out an attitude of great concern in caring for nature and its environment in earnest. Being human, they realize that they are part of nature and are not separate from nature. Even humans view nature as their fellow human beings, which means fellow subjects are equal to humans, not under human authority. Speaking of religion, in primitive spiritual structures as Honig explained that: primitive man saw the world not as an object, as material for his actions, but he saw himself as one of the many subjects, from which the world was constituted of Honig [4].

Tracing the way of thinking, how to know, and express something aforementioned above, thus the Sedulur Sikep community has had a clear discourse on their attitudes and responses to their natural environment. The Sedulur Sikep community cannot be separated from the natural environment which is loaded with lemah garapan (paddy fields), especially agricultural nature in which the people process and maintain. From the mbrokohi ritual of the Sedulur Sikep rice harvest, the visible teaching as a discourse out of defining the uba-rampe symbols with their meaning (eco-doctrinal). The mbrokohi rice harvest ritual of the Sedulur Sikep community has a core local narrative of life as a teaching of caring for nature and the environment. Using Barthesian semiotic analysis, the meanings of mbrokohi rice harvest ritual can be scientifically explained.

The explanation of the discourse of a symbolic meaning in the ritual includes uba-rampe jenang abang putih Sedulur Sikep people realize their existence on this earth. Their existence begins with a sexual encounter between men (semen) with women (eggs). It also reminds the people of Sedulur Sikep to understand the existence of life through symbolic transformation of the two realms, namely heaven and earth which meet to create life. Both of these realms. Produce "marriage" between the sky called "Bapa akasa" by the earth they call "Ibu Bumi" or Mother of Earth. The peak of fertilization is the fall of rain from top to bottom, namely to the earth. The rain is a manifestation of transformation at the peak of fertilization, thus the semen flows from the father to the motherland so as to produce the fertility of plants and create prosperity [5][6].

Following the ubo-rampe ritual mbrokohi rice harvest community of Sedulur Sikep is wedang kendi which is clear and mature white water placed in a clay jug. This is a meaningful sign that the person and soul of the Sedulur Sikep community have a heart full of peace and a pure and clear mind. Then sego gudhangan (urap rice) is white rice supplemented with boiled kenikir leaf vegetables and given spicy young coconut shavings and sprouts, in addition to salted fish. This is a reflection and teaching that the Sedulur Sikep community as a person who should have a lifestyle sing prasaja ora neka-neka (simple and uncomplicated person).

The last is iwak ingkung which symbolically means sujud manembah (pray and worship) ingkung (whole cooked chicken), namely native chicken that has been tied to its feet and then cooked with opor seasoning complete with coconut and Salam leaves. However, for the Sedulur Sikep community who are unable to afford so, they can alternatively use the iwak ingkung as a condition for the holding of a ritual, everything that is determined together remains respected and appreciated. The life of the Sedulur Sikep community shows the spirit of sacrifice in the interest of the community together. Based on the all served ubo-rampe ritual, then they are enjoyed by relatives by eating and drinking together, friends, or neighbors who witness the results of rice grains that are ready to be harvested. For the Sedulur Sikep community who will hold the mrbokohi rice harvest ritual, they will always invite and gather some of the Sedulur Sikep community members either at nggarapan (rice field) before 
harvesting rice or it can also be done at pondhokan (home) after a day of rice harvest is complete.

Based on explanations of the symbolic meanings of the ubo-rampe in mbrokohi ritual of Sedulur Sikep's rice harvest, this community confirmed the existence of a reality discourse that manifests power or authority as well as the Sedulur Sikep community's life views. Sedulur Sikep constitute of an agrarian society that has great concern for the natural environment, especially in the agricultural sector. The strength of the discourse and symbols expressed the Sedulur Sikep community turned out to have the strong roots and needed to be maintained. That spirit encourages the courage of Sedulur Sikep to fight the arising all sorts of stigma in the community and anticipate changes in an increasingly modern era.

\subsection{The Steps in Anticipating and Resisting the Stigma}

Stigma deals with a variety of views of people who judge a person negative. In its development, in the social arena found stigmatization, namely giving a sign (stigma) to a person or group of people with a negative meaningful understanding in certain situations and contexts openly or veiled in influencing the thinking power of a person or group of people towards something in the interests of the giver of stigma. Sedulur Sikep community is one of the victims of stigmatization from the wider community. As stated by Mr. Ganjar Pranowo governor of Central Java in the opening words of the book Samin mysticism of farmers in the midst of upheaval, as Anis Sholeh Ba'asyin and Muhamad Anis Ba'asyin [7] emphasized. Whereas in the past, there were many parties who used the word "Samin" as a mockery. The term is analogous to stubborn, naive, arbitrary, and other negative designations. This was actually done by the colonizers for a long time to the Samin community.

The Dutch colonial rulers were confused by the way the Samin people did their resistance through their original attitude which was a reflection of the philosophical life of the people. Thus, since then the colonial authorities arrested the Samin movement figures and dumped them outside of Java. When that effort was unsuccessful, the colonial authorities categorized or stigmatized: the Samin people were identical with primitive people who were stupid and uncultured and their existence had to be shunned [7]. The same thing as I have encountered in the wider environment that the term "Samin" also has a negative connotation because the syllable "min" explains negative things (-) or less, not "plus" (+), so the understanding is getting worse. The conditions experienced by the Samin community or Sedulur Sikep cannot be left alone. This means that by Sedulur Sikep itself the community needs to be humble, be an open figure in accepting change but at the same time also dare to countermeasure or anticipate its possibilities.

As such, it is not surprising that the people of Sedulur Sikep have calculations about what will happen to them and have a mental adjustment to what they will experience. This attitude actually shows a typical subtle resistance is not open to the stigmatization of society. This is a typical resistance action, namely how the resilience or heart and soul of the Sedulur Sikep community to withstand something being tested. According to James Scott there are several forms of resistance, namely: 1) Hidden transcripts (symbolic or ideological resistance) are symbolic or ideological rejection of categories imposed on society. For example; gossip, slander, rejection of what was forced on society, and the withdrawal of respect for the authorities. 2) Public transcript (public or open resistance) is typical of organized, systematic and principled resistance. The embodiment of such resistance is realized through violent means such as rebellion. These two categories that Scott classified, are distinguished by the 
articulation of resistance, form, characteristics, social and cultural territory. Open resistance is characterized by open interactions between subordinate classes and superordinate classes [8].

The manifestation of anticipation and resistance shown by Sedulur Sikep community is a typical hidden transcript or hidden resistance. This is symbolic or ideological and is a rejection of the categories imposed on the Sedulur Sikep community in the form of social stigmatization. Therefore, since the Dutch colonial era until now, the form of defense is still the same, namely maintaining the motherland. The purpose of behaving like this is to maintain cultural traditions and teachings of loyalty to a belief in protecting the earth's natural environment, especially in cultivating land and farming. Self-defense is manifested in a prohibition or taboo instruction as a form of anticipation as well as resistance. This is as confirmed in the interview with Mrs. Gunarti in Sukolilo and Mr. Budi reside in Kudus regency, which emphasized that the Sedulur Sikep community had held the five prohibited orders from their ancestors or parents as a form of teaching that has been obeyed until now. The prohibition or five restrictions as written as secondary data as reported by Rosyid [9] are: not allowed to attend formal and informal schooling, may not wear long pants, may not wear a hat, may not trade, and may not be polygamy. The analysis that was found related to resistance and anticipation by Sedulur Sikep community on their stigma shows that they are human beings with dignity and culture. With their culture and dignity as human beings, they live socially in the midst of the swift currents of modernization.

First, the Samin community is not permitted to attend formal schooling. According to Sikep people responding to formal school activity as emphasized "sekolah karepe ben pinter ning yen wis pinter terus minteri" the desire to go to school in general is aimed at getting smarter but after succeeding in becoming smart and then fooling others. Based on this cultural expression, it actually reflects a traumatic sense of their collective experience since colonial rule. That the community is often fooled by people who are educated and have completed their formal schooling. This is a closed form of resistance to educational capitalism which is very likely to create oppressive classes for the people. In addition, formal schooling results in their children spending time at school with their assignments and can no longer be monitored and educated by parents who focus on the noble task of cultivating land and farming. This is a concept that is implanted in anticipating that their descendants do not easily leave their homeland alone. If school is identical with the term student, in fact their children have got a real teacher that is their own parents at home and this nature as their school room.

Second, people should not wear long pants. For the people of Sedulur Sikep in the past, long pants were pants introduced by the colonial invaders. Because the general clothing at that time was still using gloves or shorts. This was done as a form of closed resistance, the people of Sedulur Sikep were reluctant to compromise or the pants they were wearing did not want to be compared to the invaders' pants. Even now the prohibition is used against the influence of food capitalism where people never want to know or don't want to go down into the fields dirty with mud. Therefore, the Sedulur Sikep community must anticipate by continuing to wear suwal tokong (shorts just below the knee as farming pants) they cultivate the land directly and continue to farm persistently to produce their own crops.

Third, the Samin community is not permitted to wear a cap. From the beginning, the Sedulur Sikep community only knew udheng, a cloth headband. In addition to protecting the head udheng also serves to wipe the sweat that comes out of the head. Considering their work in paddy fields and farming must have been stricken by the scorching heat of the sun, it is not surprising if the fluid in the body burns out of sweat. When their eyes glare with the heat of the sun, it is not uncommon for the people of Sedulur Sikep to work on the rice fields wearing caping headgear. An object called a cap, is still very foreign, moreover it will be placed on the 
head where the head is the center of control of the whole body. Then the people of Sedulur Sikep reject cap as something that neither belong to them nor they recognize it. This is according to teaching "wong Samin ngerti mbi theke dhewe" (Samin people know their own) They will fight, if something strange is precisely going to threaten and control their bodies and communities. The aforementioned thing is a stranger or a foreign discourse that threatens, colonizes and rules over the Sedulur Sikep's mother land.

Fourth, the Samin people are not allowed to trade. As light as any taboo is faced by the Sedulur Sikep community for not trading, it is a form of closed resistance to economic capitalism. They forbid trading while saying "yen kulake sewu ya edolen sewu apa sakngisore, yen mbok regani sakndhuwure iku wis kadunungan goroh" (if the wholesale price is a thousand, then the price is one thousand, or below, if you sell at the price above it, then you are lying). According to Sedulur Sikep, trading is an economic activity that cannot be separated from lies [10]. With this anticipatory step they are directed to focus more on their work in agriculture to cultivate the rice field or garapan sawah.

Fifth, the Samin people must not lead a life of polygamy. Sedulur Sikep society does not allow to have more than one wife or husband, considering they always think simple but very well founded. They argue that "langit kuwi gur siji, bapa akasa kuwi mula ya siji, ibu bumi kuwi ya gur siji, siji ketemu siji, yen thukule isa wae loro malah luwih" (the sky is only one, then the father is also only one, and the mother earth is only one, one meets one, if the plants can live in number two or even more) from their natural lessons are against the exploitation of the population and forms of anticipation of the growing conflict of a family. Thus, polygamy is a principle of marital relationship that is not recommended or permitted by the Sedulur Sikep community. Departing from all forms of closed resistance and anticipatory measures, in fact a essence and purpose of the life of the Sedulur Sikep community is to re-concentrate and offer the lives of the Sedulur Sikep to nature as fellow entities. So, they try to involve themselves fully in carrying out the mission of preserving nature and the environment by protecting and caring for it.

\section{Conclusion}

Uniqueness is synonymous with having a special value and is exclusive. Especially the traditions and culture of the people in Sukolilo. From various traditional ceremonies and rituals carried out, the mbrokohi ritual of the Sedulur Sikep community's rice harvest is quite unique in addition to providing basic information from a natural belief in Samin's followers in Bombong Dukuh, Batureja Village, Sukolilo District, Pati Regency. Through exploring and analyzing the research subjects about the mbrokohi rhythm of rice harvest in the Sedulur Sikep community, it was found traditionally that in carrying out the ritual of mbrokohi rice harvest Sedulur Sikep which was laden with symbolic meaning (eco-ritual), the Sedulur Sikep community had received a natural teaching (eco-doctrinal) as the power of discourse and symbols which enable them to be able to fight the stigma and influence of the modern era with a noble aim in preserving nature and the environment (eco-praxial).

Based on the findings presented, it is suggested to the people of Sedulur Sikep to remain strong in holding on to their beliefs, despite the fact that there is still so much stigma attached by some people to the Sedulur Sikep community. For academics, it is hoped that through their scientific research and studies, besides supporting the preservation of the cultural traditions of the Sedulur Sikep community with this local uniqueness and uniqueness. It is not the other way around, which is precisely trying to change their discourse on the pretext of progress and 
modernization. Thus, both the general public and academic intellectuals are mutually supporting each other in respecting and valuing the uniqueness and local wisdom, especially in organizing the Sedulur Sikep's rice paddy ritual in Dukuh Bombong, Batureja Village, Sukolilo District, Pati Regency.

\section{References}

[1] J. Kirk and M. L. Miller, Reliability and validity in qualitative research, vol. 1. Sage, 1986.

[2] M. B. Miles and A. M. Huberman, "Analisis data kualitatif." Jakarta: UI press, 1992.

[3] A. Ciptoprawiro, Filsafat jawa, vol. 3176. Balai Pustaka, 1986.

[4] J. Honig, Ilmu Agama. Jakarta: PT. BPK Gunung Mulia, 1988.

[5] N. Noordiana, A. Juwariyah, and F. Inda, "The Impact of Tayub Exploitation on The Tradition and Life of Javanese Society," Harmon. J. Arts Res. Educ., vol. 16, no. 2, pp. 133-142, 2016.

[6] M. Smith, Z. Johanson, P. M. Barrett, and M. Richter, "Introduction and bibliography," Geol. Soc. London, Spec. Publ., vol. 430, no. 1, pp. 1-29, 2016.

[7] A. S. Ba'Asyin and M. A. Ba'asyin, Samin: mistisisme petani di tengah pergolakan. Gigih Pustaka Mandiri, 2014.

[8] J. C. Scott, Senjatanya Orang-orang yang Kalah: Bentuk-bentuk perlawanan sehari-hari kaum tani. Yayasan Obor Indonesia, 2000.

[9] M. Rosyid, Samin Kudus: bersahaja di tengah asketisme lokal. Pustaka Pelajar, 2008.

[10] D. Samiyono, "Sedulur sikep struktur sosial dan agama masyarakat Samin di Sukalila," Univ. Kristen Satya Wicana Salatiga, 2010. 